\title{
Experimental Research on Hydrogen and Hydrocarbon Fuel Ignition for Scramjet at $\mathrm{Ma}=4$
}

\author{
Zhang Wanzhou $^{1,2}$, Le Jialing ${ }^{2}$, Yang Shunhua ${ }^{2}$, Cheng Wenming ${ }^{1}$, Deng Weixing ${ }^{1,2} \&$ Zhou Huabo $^{2}$ \\ ${ }^{1}$ School of Mechanical Engineering, Southwest Jiaotong University, Chengdu, China \\ ${ }^{2}$ Science and Technology on Scramjet Laboratory, Hypervelocity Aerodynamics Institute of CARDC, Mianyang, \\ Sichuan, China \\ Correspondence: Zhang Wanzhou, School of Mechanical Engineering, Southwest Jiaotong University, Chengdu, \\ China. Tel: 86-187-8118-6368. E-mail: zwz8410@gmail.com
}

Received: December 3, 2012 Accepted: February 19, $2013 \quad$ Online Published: February 26, 2013

doi:10.5539/mas.v7n3p56 URL: http://dx.doi.org/10.5539/mas.v7n3p56

\begin{abstract}
Ignition experiments of Hydrogen and Ethylene were performed on direct-connected pulse combustion facility. Air stagnation temperatures were $900 \mathrm{~K}$ and stagnation pressures were $0.8 \mathrm{MPa}$, the entrance Mach number was approximate 2.0 provided by a two-dimension nozzle. The experimental results indicate that: (1) Hydrogen self-ignition won't occur at stagnation $935 \mathrm{~K}$ when it is injected upstream the cavity in this combustor model. But with low input power igniter, hydrogen can be ignited reliably. (2) Ethylene cannot be ignited with igniter only even at high igniter power. Under the assistant of both igniter and pilot Hydrogen, Ethylene can be ignited reliably and maintain stable combustion after the igniter and pilot hydrogen completely turned off. (3) The lowest equivalence ratio of pilot hydrogen for successful ethylene ignition is 0.05 below that ignition will fail. (4) When pilot hydrogen and igniters were both employed for ignition, the function of igniter is to ignite the hydrogen and the input power of igniter has no influence on ignition performance.
\end{abstract}

Keywords: scramjet, ignition, hydrocarbon fuel, engine design

\section{Introduction}

In Turbine based combined cycle (TBCC) propulsion system, the turbojet engine provides its highest speed of Ma 3-4, then the Scramjet engine should startup near Mach 4 and maintain appropriate performance to accelerate to higher speed. The stagnation temperature of the flow captured at flight Mach number 4 is only 800-1000 K, the static temperature of the supersonic flow in the combustor is about 500-600 K, lower than the self-ignition temperature of most fuel. The research on assistant ignition methodology for Scramjet engine at low stagnation temperature is necessary.

There are four major factors for successful ignition at low stagnation temperature flow: high static temperature, low velocity, sufficient mixing of fuel and oxidizer and combustion radicals. Common assistant ignition technique includes: (1) Igniter. Igniters, producing a small high temperature region in the flow-field such as spark (Chadwick et al., 2005), flame torch, arc discharge (Aleksandrov et al., 2006) etc. and also releasing lots of radicals such as plasma torch (Watanabe, Abe, \& Takita, 2009), could effectively assist for ignition and combustion. (2) Fuel technology. Fuel technology includes fuel additive and calefaction. Additives for fuel can effectively facilitate fuel ignition and combustion but most of them are poisonous to environment and staff. Some researcher heat the fuel to 500-600 K (Mathur et al., 2000) or even to the supercritical state to simulate the fuel as coolant in real flight situation, and this also will help for ignition and combustion. (3) Fuel mixing enhancement. Sufficient mixing of fuel and oxidizer can reduce the ignition delay and promote combustion. Mixing enhancement devices are employed in scramjet combustor such as physic ramp and aerodynamic ramp (Wang, Song, Li, \& Cai, 2008) injectors, strut injectors and atomization technology for liquid fuel. The aerated-liquid jet (Lin, Kirkendall, Kendedy, \& Jackson, 1999; Lin, Kendedy, \& Jackson, 2000; 2002) being developed for years has proved its effect on reducing the liquid droplet diameter and improving for the local equivalence ratio if the gas is air or oxygen (Segal, 2009). (4) Air throttle technical. Air throttle mechanism (Yang, Li, Choi, \& Lin, 2010) that usually be settled at downstream of the combustor can induce shock chains to slowdown the velocity of core flow and increase the static temperature in the combustor, which will facilitate the ignition. Once ignition succeeds, withdraw air throttle at right time and stable combustion could maintain (Lin et 
al., 2007; Mathur et al., 1999). All the experiments presented above were performed on continuous facility, continuous facility can provide longer igniting time and ignition processe started at hot wall temperature condition which has been proved to be efficient methods to facilitate ignition at low total temperature inflow. These ignition experiments were carried out on the pulse facility, pilot hydrogen and torch igniter were employed as assistant for ignition, by adjusting the injection schemes and ignition time, Hydrogen and gaseous ethylene ignition succeed and stable combustion maintained at stagnation temperature approximate $900 \mathrm{~K}$.

\section{Facility Introductions}

\subsection{Pulse Directly-Connected Combustion Facility}

The facility consists of Ludwieg tube, Hydrogen supply system, heater, settling chamber, test section and vacuum tank (Figure 1). The hydrogen fueled heater was used to achieve the air stagnation temperature of $900 \sim 1900 \mathrm{~K}$, which corresponds to a range of flight Mach numbers 4 7. Stable experimental time is about 250 ms. Total temperature and inflow Mach number of the inflow gas are verified by thermal couple, Pitot Pressure measurement and cavulation respectively. For this experiment, the ideal parameters and actual parameters are listed in Table 1.

Table 1. Experimental parameters of facility

\begin{tabular}{cccccc}
\hline & $\begin{array}{c}\text { Flight Ma } \\
{[-]}\end{array}$ & $\begin{array}{c}\text { Inflow Ma } \\
{[-]}\end{array}$ & $\begin{array}{c}\mathrm{Tt} \\
{[\mathrm{K}]}\end{array}$ & $\begin{array}{c}\text { Pt } \\
{[\mathrm{MPa}]}\end{array}$ & $\begin{array}{c}\text { Mass Flow rate } \\
{[\mathrm{kg} / \mathrm{s}]}\end{array}$ \\
\hline Ideal parameters & 4 & 2 & 900 & 0.8 & 3.09 \\
Actual parameters & 4 & 2.1 & 935 & 0.8 & 3.09 \\
\hline
\end{tabular}

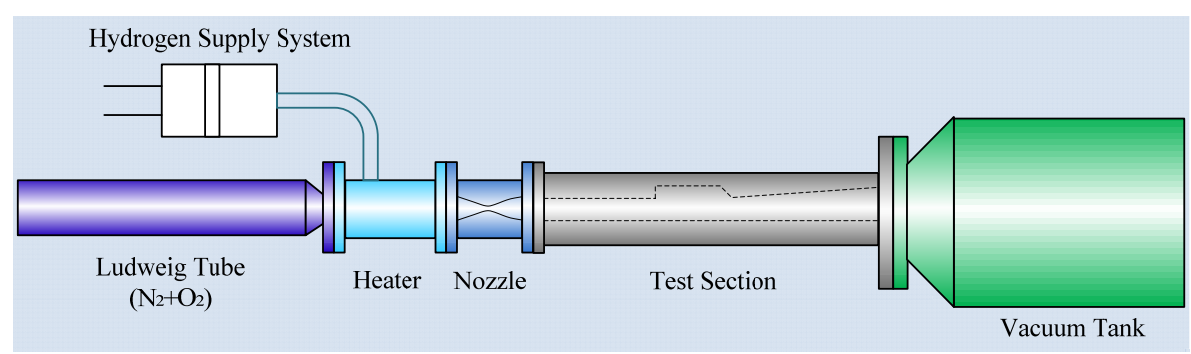

Figure 1. The directly-connected pulse combustion facility

\subsection{Torch Igniter}

The igniter employed in the experiments is Hydrogen-Air torch igniter, it consists of three subsystems: the hydrogen supply system, the air supply system and the spark (Figure 2). The spark igniter the mixture of Hydrogen and air, then the hot gas after combustion injects into the flow-field from the cavity floor. The rated thermal power of igniter is approximate $70 \mathrm{~kW}$, and the input power can be adjusted by changing the upstream pressure of Hydrogen and air. Two igniters are settled on the cavity floor but each is controlled individually. The total input power of igniter can be adjusted among $20 \mathrm{~kW}-180 \mathrm{~kW}$. 


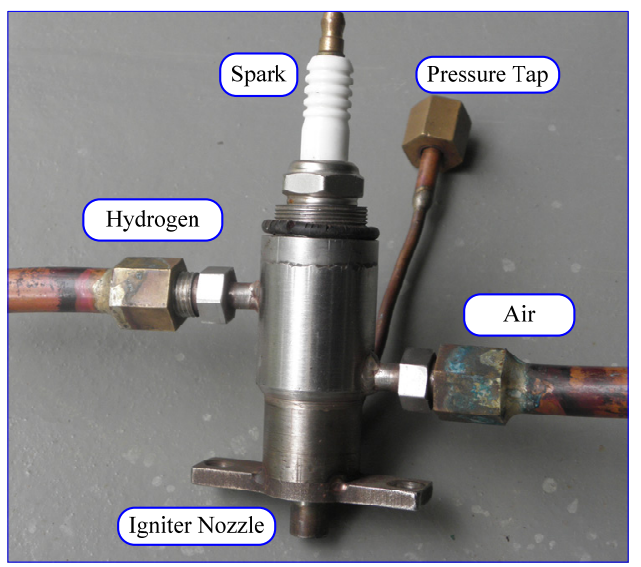

Figure 2. Torch igniter

\subsection{Scramjet Combustor Test Model}

The entrance cross section of isolator is $50 \mathrm{~mm}$ height by $100 \mathrm{~mm}$ width, total length is $1700 \mathrm{~mm}$. The top wall consists of several diverges at different angles and the bottom wall is flat, a cavity used as flame-holder is settled on the top wall which is characterized by depth $=18 \mathrm{~mm}, \mathrm{~L} / \mathrm{D}=10.8$ and a ramp angle of $22.5^{\circ}$ (Figure 3). Pressure sensors are installed on sidewall of the combustor model (Figure 4).

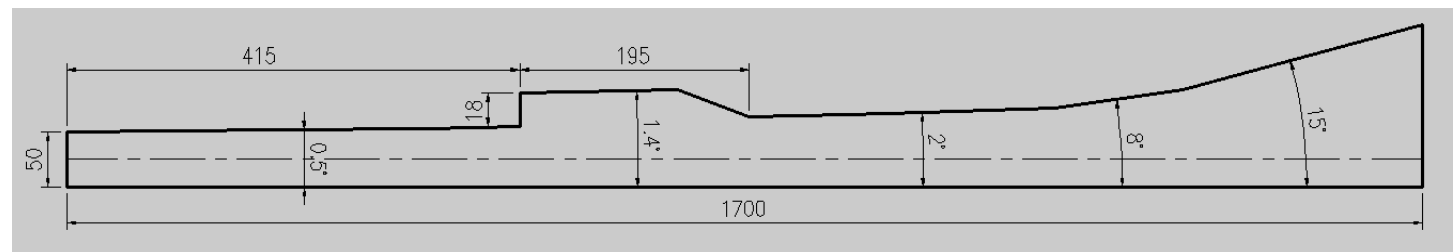

Figure 3. Side-view of the scramjet combustor configuration (units: $\mathrm{mm}$ )

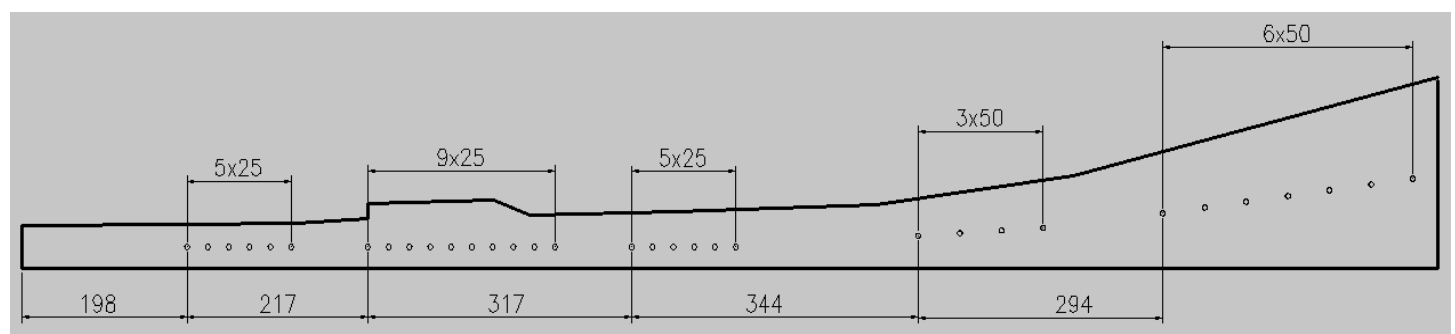

Figure 4. Locations of pressure sensors on side wall of combustor model (units: $\mathrm{mm}$ )

Eight fuel injection positions were designed around the cavity, four were used in these experiments (Figure 5): upstream of the cavity (A), on the cavity floor (B) and downstream the cavity (C, D). Each position located twelve 1-mm-diameter injectors that were $8 \mathrm{~mm}$ apart. All the injection positions are controlled individually.

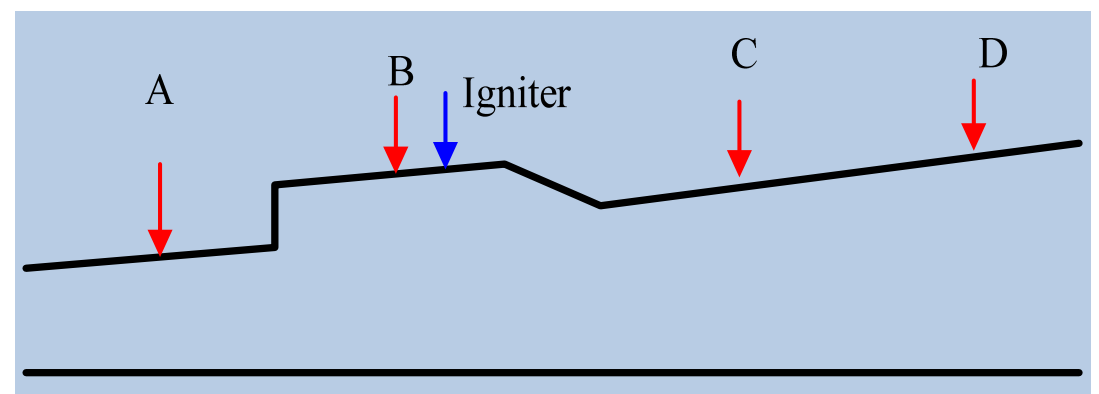

Figure 5. Positions of cavity, injectors and igniter 


\subsection{Experimental Schedule}

The typical experimental schedule is: facility starts $\rightarrow$ igniter on $\rightarrow$ pilot hydrogen injecting on $\rightarrow$ ethylene injecting on $\rightarrow$ igniter off $\rightarrow$ pilot hydrogen off $\rightarrow$ ethylene off $\rightarrow$ facility end. Time from pilot hydrogen injecting on to igniter off was defined ignition time (Figure 6), and it could be measured according to the igniter pressure and pilot hydrogen injection pressure. Time from pilot hydrogen off to ethylene off is defined maintain combustion time. If ethylene could maintain stable combustion after igniter and pilot hydrogen completely shut off, it indicates ignition succeed.

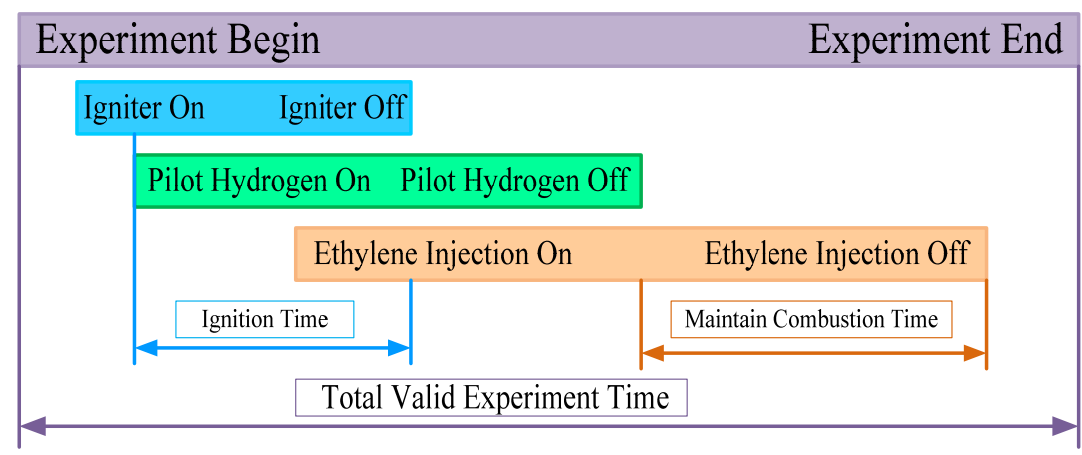

Figure 6. Schematic of ignition experiment system

\subsection{Fuel/Air Ratio}

Fuel/air ratio is an important parameter in scramjet combustor. The fuel/air ratio is defined as:

$$
\frac{\text { Fuel mass flow rate }}{\text { Entryairmass flow rate }}=f=\frac{\dot{m}_{f}}{\dot{m}_{A}}
$$

The ideal fuel/air ratio is named as stoichiometric fuel/air ratio which means the oxygen in the air can react with all the reactants available in the fuel. For hydrogen and hydrocarbon fuels the chemical equation is:

$$
\mathrm{C}_{x} \mathrm{H}_{y}+\left(x+\frac{y}{4}\right)\left(\mathrm{O}_{2}+\frac{79}{21} \mathrm{~N}_{2}\right) \rightarrow x \mathrm{CO}_{2}+\frac{y}{2} \mathrm{H}_{2} \mathrm{O}+\frac{79}{21}\left(x+\frac{y}{4}\right) \mathrm{N}_{2}
$$

Then the stoichiometric fuel/air ratio is defined as:

$$
f_{s t}=\frac{36 x+3 y}{103(4 x+y)}
$$

The equivalence ratio to describe the fuel/air ratio is defined as:

$$
\varphi=\frac{f}{f_{s t}}
$$

\section{Experiment Results and Analysis}

Ethylene and hydrogen ignition experiments were carried out at stagnation temperature $935 \mathrm{~K}$. Gaseous ethylene and hydrogen were successfully ignited by adjusting fuel equivalence ratio, igniter input power, ignition time and fuel schedule. Pressure distribution was measured and ignition parameters and experience were obtained.

\subsection{Hydrogen Self-ignition Experiments}

Experiments on hydrogen self-ignition had carried out at different conditions with hydrogen injected upstream the cavity, and hydrogen self-ignition never occurred. During the experiments cavity configurations, hydrogen equivalence ratio had been varied. It indicates that some orther assistant ignition mechanism is necessary for pilot hydrogen and ethylene ignition.

\subsection{Ethylene Ignition Experiments with Torch Igniters}

Ethylene ignition experiments at different injection schemes, equivalence ratios and cavity configurations had been performed with torch igniter for assistant, the torch igniter input power varied from $50 \mathrm{~kW}$ to $150 \mathrm{~kW}$, ethylene ignition never achieved. These results indicate that the torch igniter is not competitive for ethylene ignition and some other assistant methods are required. 


\subsection{Hydrogen Ignition Experiments at Various Igniter Input Power}

Two igniters was equipped on the test model, there are two ways to vary the igniter input power: (1) vary the supply pressure of hydrogen and air to change the individual input power; (2) using one or two igniters for each experiment to change the total input power. For hydrogen ignition experiments, the total input power was varied from $20 \mathrm{~kW}-140 \mathrm{~kW}$ (Table 2), at different cavity configurations and fuel injection schemes, hydrogen were ignited successfully and maintained stable combustion.

Table 2. Hydrogen ignition experiments at different igniter input power

\begin{tabular}{ccccccc}
\hline No. & $\begin{array}{c}\text { Injection } \\
\text { Position }\end{array}$ & $\begin{array}{c}\text { Equivalence } \\
\text { Ratio }\end{array}$ & $\begin{array}{c}\text { Igniter } \\
\text { Amount }\end{array}$ & $\begin{array}{c}\text { Igniter Power } \\
\mathrm{kW}\end{array}$ & $\begin{array}{c}\text { Ignition Time } \\
\mathrm{ms}\end{array}$ & Results \\
\hline 052202 & $\mathrm{~A}+\mathrm{C}$ & $0.1+0.2$ & 2 & $50.0+50.0$ & 30 & succeeded \\
053101 & $\mathrm{~B}+\mathrm{C}$ & $0.13+0.37$ & 2 & $55.7+55.7$ & 50 & succeeded \\
052104 & $\mathrm{~A}+\mathrm{C}$ & $0.11+0.11$ & 2 & $65.5+65.5$ & 30 & succeeded \\
052103 & $\mathrm{~A}$ & 0.25 & 2 & $71.1+71.1$ & 30 & succeeded \\
052501 & $\mathrm{~B}+\mathrm{C}$ & $0.30+0.16$ & 1 & 46.0 & 30 & succeeded \\
052302 & $\mathrm{~A}$ & 0.32 & 1 & 47.4 & 30 & succeeded \\
052401 & $\mathrm{~A}+\mathrm{B}$ & $0.19+0.22$ & 1 & 55.7 & 30 & succeeded \\
052304 & $\mathrm{~B}$ & 0.28 & 1 & 57.8 & 30 & succeeded \\
071602 & $\mathrm{~A}$ & 0.05 & 1 & 20 & 30 & succeeded \\
\hline
\end{tabular}

At a wide range of torch igniter input power, hydrogen could be ignited successfully and reliably at different injection schemes, equivalence ratio and ignition time. Results from Table 2 proved that there is no severe problem on hydrogen ignition at stagnation temperature $935 \mathrm{~K}$, and hydrogen is suitable as a pilot fuel.

\subsection{Pilot Hydrogen Limit for Ethylene Ignition Experiments}

Pilot hydrogen is necessary for ethylene ignition as torch igniter is not competitive. A series of experiments were performed to find the equivalence ratio limit of pilot hydrogen below which ethylene ignition would be impossible.

Ethylene was injected from the cavity floor at equivalence ratio is approximate 0.2 . The total input power of igniters is $80 \mathrm{~kW}$ which was determined based on Table 2 to ensure successful pilot hydrogen ignition, pilot hydrogen was injected upstream of the cavity. The equivalence ratio of hydrogen reduced from 0.12 till ignition failed (Table 3).

Table 3. Ignition experiments on pilot hydrogen limit

\begin{tabular}{ccccccc}
\hline \multirow{2}{*}{ No. } & \multicolumn{2}{c}{ Ethylene } & \multicolumn{2}{c}{ Pilot Hydrogen } & Igniter & Ignition \\
\cline { 2 - 5 } & $\begin{array}{c}\text { Injection } \\
\text { Position }\end{array}$ & $\begin{array}{c}\text { Equivalence } \\
\text { Ratio }\end{array}$ & $\begin{array}{c}\text { Injection } \\
\text { Position }\end{array}$ & $\begin{array}{c}\text { Equivalence } \\
\text { Ratio }\end{array}$ & $\begin{array}{c}\text { Energy } \\
\text { results }\end{array}$ \\
\hline 071303 & B & 0.194 & A & 0.12 & $80 \mathrm{~kW}$ & succeeded \\
071304 & B & 0.202 & A & 0.079 & $80 \mathrm{~kW}$ & succeeded \\
071501 & B & 0.202 & A & 0.049 & $80 \mathrm{~kW}$ & succeeded \\
071701 & B & 0.20 & A & 0.034 & $80 \mathrm{~kW}$ & failed \\
\hline
\end{tabular}




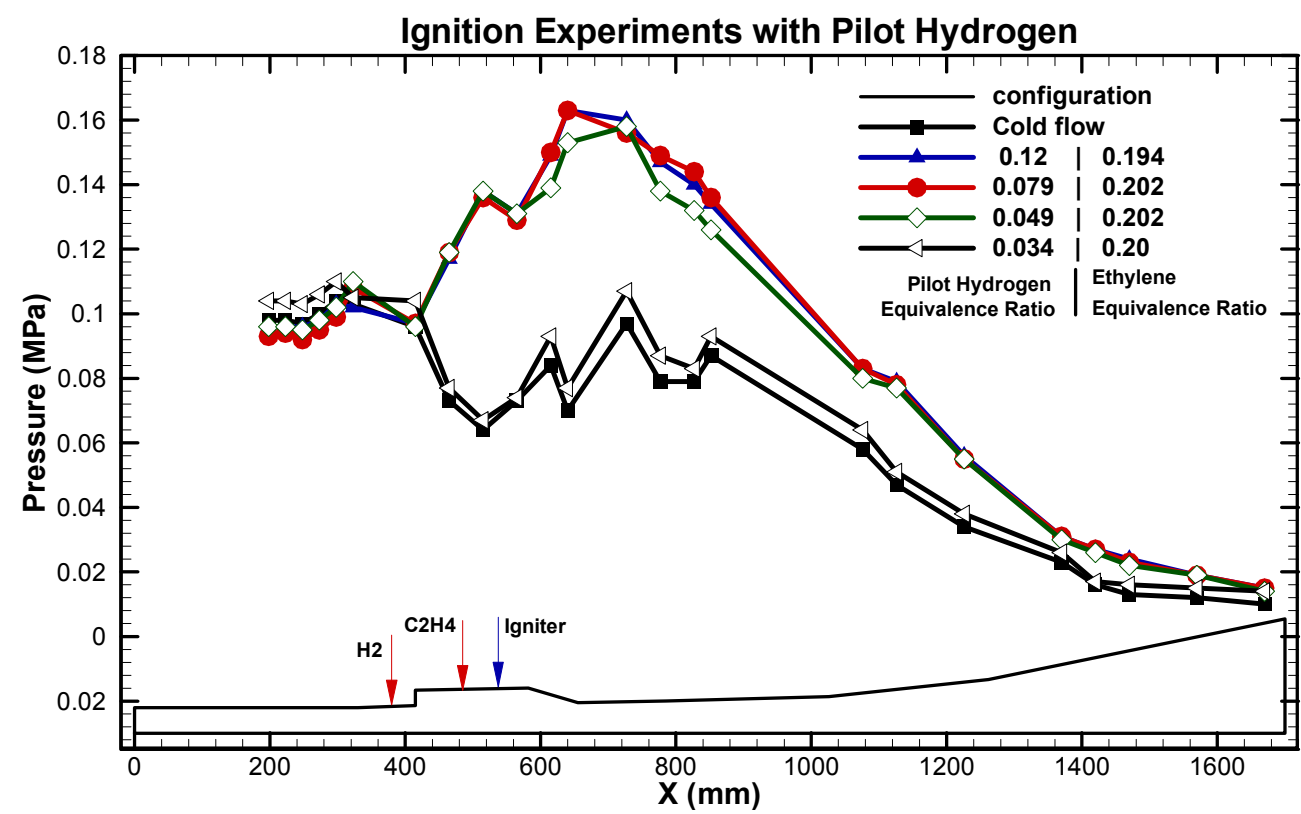

Figure 7. Wall pressure of ignition experiments on pilot hydrogen limits

The wall pressure in Figure 7 was measured $100 \mathrm{~ms}$ after pilot hydrogen and torch igniters were completely shut. These four experiments with almost the same experimental parameters except hydrogen equivalence ratio, when the hydrogen equivalence ratio reduced to 0.034 , ethylene ignition failed, the wall pressure agreed with cold flow wall pressure well. Also as the Figure 7 shows, with similar ethylene equivalence ratio, after hydrogen and igniter turned off, the wall pressure of combustor agreed well which proved that the hydrogen equivalence ratio has little effect on combustor wall pressure.

\subsection{Ethylene Ignition Experiments at Various Igniter Input Power Combined with Pilot Hydrogen}

Experiments were performed to research on the igniter input power for ignition. The pilot hydrogen was injected upstream the cavity at equivalence ratio of 0.05 , ethylene was injected from the cavity floor at equivalence ratio of 0.2. Combustor wall pressures were measured when igniter and hydrogen were shut $100 \mathrm{~ms}$ later.

The Figure 8 shows the experiments details. The curves are different from cold flow wall pressure curve which means ethylene ignition achieved for all experiments. The pressure curves at igniter input power $116 \mathrm{~kW}$ and 44 $\mathrm{kW}$ were much lower than the other four curves, after analyzing the differences is induced by the ethylene equivalence ratio. The pressure curve at igniter input power $20 \mathrm{~kW}$ agree with the other three curves well before $650 \mathrm{~mm}$, after the wall pressure reduced, this may be caused by the igniter input power and ethylene equivalence ratio both. The results also indicate that the function of igniter is to ignite pilot hydrogen which serves as source of heat and combustion radicals, and then ignite the ethylene. 


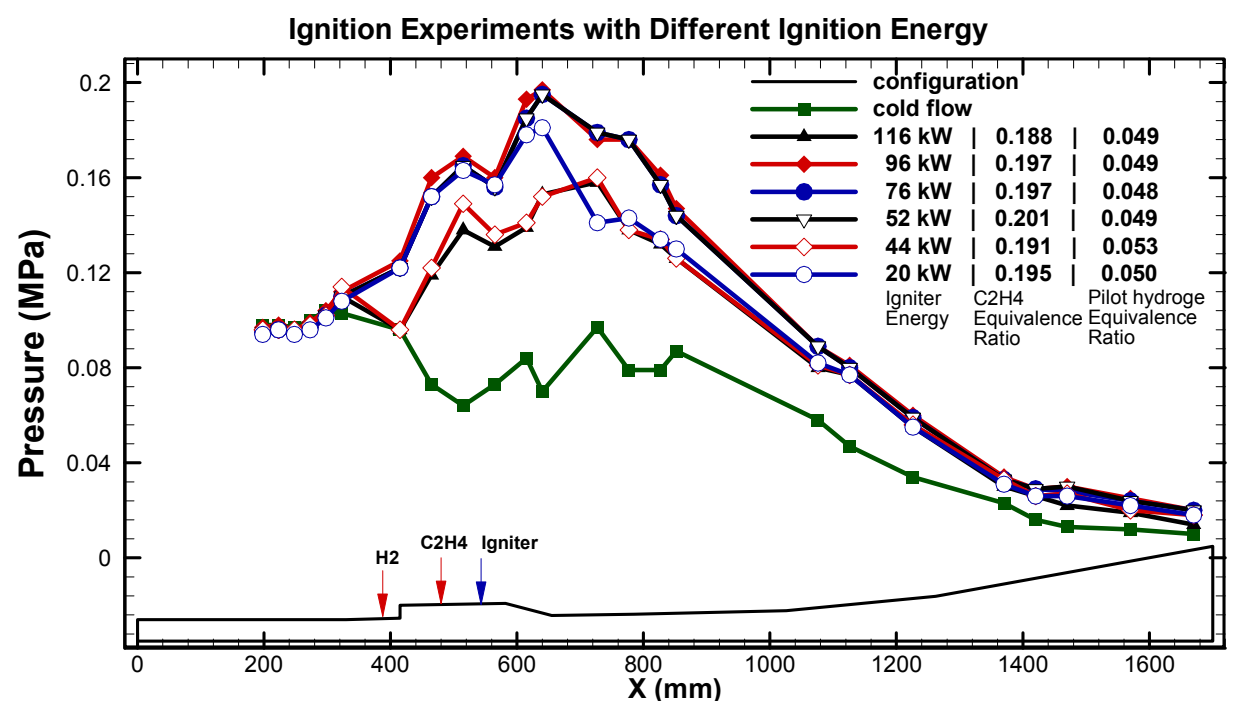

Figure 8 . Wall pressure of ignition experiments on igniter input power

\section{Conclusions}

Ignition experiments at stagnation temperature of $935 \mathrm{~K}$ were carried out on pulse facility, experimental technical for pulse facility was mastered, the ignition performance of low stagnation flow-field was researched, and some conclusions were summarized:

(1) Hydrogen self-ignition won't occur at stagnation $935 \mathrm{~K}$ when it is injected upstream the cavity in this test model. But with low input power igniter, hydrogen can be ignited reliably.

(2) With the igniter for assistant only, ethylene could not be ignited even at high input power of $172 \mathrm{~kW}$. Igniter combined pilot hydrogen, ethylene had been ignited reliably and maintained stable combustion even at very low input power of $20 \mathrm{~kW}$ for igniter.

(3) When pilot hydrogen is injected upstream of the cavity, the equivalence ratio of Hydrogen, should be higher than 0.05 that ethylene can be ignited reliably and maintain stable combustion.

(4) When igniter and pilot hydrogen at equivalence ratio of 0.05 were both employed, ethylene ignition achieved in a wide range of igniter power from $116 \mathrm{~kW}$ to $20 \mathrm{~kW}$. The results indicate that the main function of igniter is to ignite pilot flame which serves as the source of heat and combustion radicals to facilitate ignition.

\section{References}

Aleksandrov, A., Bychkov, V., Chernikov, V., Ershov, A., Gromov, V., Kolesnikov, E., ... Vinogradov, V. (2006). Arc Discharge as a Means for Ignition and Combustion of Propane-Air Mixture Supersonic Flow. AIAA, 2006-1462.

Chadwick, C. R., James, F. D., Hsu, K. Y., Donbar, J. M., Gruber, M. R., \& Campbell, D. C. (2005). Stability limits of cavity-stabilized flames in supersonic flow. Proceedings of the Combustion Institute, 30, 2825-2833. http://dx.doi.org/10.1016/j.proci.2004.08.185

Lin, K. C., Kendedy, P. J., \& Jackson, T. A. (2000). Spray Penetration Heights of angled-injected aerated-liquid jets in supersonic cross-flows. AIAA, 2000-0194.

Lin, K. C., Kendedy, P. J., \& Jackson, T. A. (2002). Penetration Heights of Liquid jets in High-speed Crossflows. AIAA, 2002-0873.

Lin, K. C., Kirkendall, K. A., Kendedy, P. J., \& Jackson, T. A. (1999). Spray Structures of Aerated Liquid Fuel Jets in Supersonic Cross-flows. AIAA, 99-2374.

Lin, K. C., Tam, C. J., Boxx, I., Compbell, C., Jackson, K., \& Lindsey, M. (2007). Flame Characteristics and Fuel Entrainment Inside a Cavity Flame Holder in a Scramjet Combustor. AIAA, 2007-5381.

Mathur, T., Lin, K. C., Kennedy, P., Gruber, M., Donbar, J., Jackson, T., \& Billig, F. (2000). Liquid JP-7 Combustion in a Scramjet Combustor. AIAA, 2000-3581.

Mathur, T., Streby, G., Gruber, M., Jackson, K., Donbar, J., Donaldson, W., ... Smith, C. (1999). Supersonic 
Combustion Experiments with a Cavity-based Fuel Injector. AIAA, 99-2102.

Segal, C. (2009). The Scramjet engine: processes and characteristics. New York: Cambridge University Press. http://dx.doi.org/10.1017/CBO9780511627019

Wang, D., Song, W. Y., Li, J. P., \& Cai, Y. H. (2008). Investigation of Hydrocarbon-fuel ignition and combustion in scramjet combustor. Journal of Solid Rocket Technology, 31(5).

Watanabe, J., Abe, N., \& Takita, K. (2009). Effect of a Rearward-Facing Step on Plasma Ignition in Supersonic Flow. Journal of Spacecraft and Rockets, 46(3), 561-567. http://dx.doi.org/10.2514/1.39018

Yang, V., Li, J., Choi, J. Y., \& Lin, K. C. (2010a). Ignition Transient in an Ethylene Fueled Scramjet Engine with Air Throttling Part I: Non-Reacting flow Development and Mixing. AIAA, 2010-409.

Yang, V., Li, J., Choi, J. Y., \& Lin, K. C. (2010b). Ignition Transient in an Ethylene Fueled Scramjet Engine with Air Throttling Part II: Ignition and Flame Development. AIAA, 2010-410. 